\title{
Effects of feeding Bt MON810 maize to sows during first gestation and lactation on maternal and offspring health indicators
}

\author{
Maria C. Walsh ${ }^{1}$, Stefan G. Buzoianu ${ }^{1,2}$, Gillian E. Gardiner ${ }^{2}$, Mary C. Rea ${ }^{3,4}$, Orla O’Donovan ${ }^{2}$, \\ R. Paul Ross ${ }^{3,4}$ and Peadar G. Lawlor ${ }^{1 *}$ \\ ${ }^{1}$ Teagasc, Pig Development Department, Animal and Grassland Research and Innovation Centre, Moorepark, \\ Fermoy, County Cork, Republic of Ireland \\ ${ }^{2}$ Department of Chemical and Life Sciences, Waterford Institute of Technology, Waterford, County Waterford, \\ Republic of Ireland \\ ${ }^{3}$ Teagasc, Food Research Centre, Moorepark, Fermoy, County Cork, Republic of Ireland \\ ${ }^{4}$ Alimentary Pharmabiotic Centre, University College Cork, Cork, County Cork, Republic of Ireland \\ (Submitted 5 October 2011 - Final revision received 13 April 2012 - Accepted 1 May 2012 - First published online 4 July 2012)
}

\section{Abstract}

A total of twenty-four sows and their offspring were used in a 20-week study to investigate the effects of feeding GM maize on maternal and offspring health. Sows were fed diets containing GM or non-GM maize from service to the end of lactation. GM maize-fed sows were heavier on day 56 of gestation $(P<0 \cdot 05)$. Offspring from sows fed GM maize tended to be lighter at weaning $(P=0 \cdot 08)$. Sows fed GM maize tended to have decreased serum total protein $(P=0.08)$, and increased serum creatinine $(P<0 \cdot 05)$ and $\gamma$-glutamyltransferase activity $(P=0.07)$ on day 28 of lactation. Serum urea tended to be decreased on day 110 of gestation in GM maize-fed sows $(P=0 \cdot 10)$ and in offspring at birth $(P=0.08)$. Both platelet count $(P=0.07)$ and mean cell Hb concentration (MCHC; $P=0.05)$ were decreased on day 110 of gestation in GM maize-fed sows; however, MCHC tended to be increased in offspring at birth $(P=0 \cdot 08)$. There was a minimal effect of feeding GM maize to sows during gestation and lactation on maternal and offspring serum biochemistry and haematology at birth and body weight at weaning.

\section{Key words: Maize: Cry1Ab (1 epidopteran-active crystalline protein): Cross-generational effects: GM food: Safety}

The genetic modification of crops has led to vast agronomic improvement and, in turn, rapid uptake of this relatively new technology. Since the introduction of GM crops in 1996, the land area used for their cultivation has increased 94-fold reaching 160 million hectares worldwide in $2011^{(1)}$. As the rate of adoption of GM crops continues to increase, so too will their consumption by animals reared for food. Consequently, the procurement of exclusively non-GM food ingredients will become increasingly difficult and expensive.

Although numerous beneficial attributes such as resistance to insect damage or inclement growing conditions are associated with the genetic modification of $\operatorname{crops}^{(1)}$, the inclusion of GM crops in animal and human food has raised some concerns regarding their safety. Consumer concerns are mostly related to a perceived risk to health, development of toxicity, allergenicity of transgenic proteins or the transfer of antibiotic resistance from the plant to bacteria residing in the gastrointestinal tract ${ }^{(2)}$. Other concerns are associated with environmental issues, such as gene transfer from GM crops to indigenous plants, reducing biodiversity and the influence of GM crops on non-target species ${ }^{(3-6)}$.

GM crops are subject to rigorous pre-market risk assessment before authorisation for release onto the European market. However, unintended consequences associated with the consumption of GM food by a genetically diverse population of humans and animals cannot adequately be evaluated during pre-market risk assessment ${ }^{(7)}$. Post-market monitoring is required to ascertain whether prolonged exposure to GM food results in responses that have been predicted by premarket risk assessment, or to reveal the presence of side effects that have been previously unpredicted.

Bt MON810 maize is engineered to express the truncated Cry1Ab toxin from Bacillus thuringiensis, which confers resistance to the European maize borer. This toxin interacts

Abbreviations: ALP, alkaline phosphatase; ALT, alanine aminotransferase; AST, aspartate aminotransferase; BW, body weight; GGT, $\gamma$-glutamyltransferase; Hct, haematocrit; MCHC, mean corpuscular Hb concentration; TP, total protein.

*Corresponding author: Dr P. G. Lawlor, fax +35325 42340, email peadar.lawlor@teagasc.ie 
with the target larvae's intestinal cells, disrupting the intestinal lining leading to death ${ }^{(8-10)}$. However, the toxin is believed to be non-toxic to mammals, birds, reptiles and amphibians due to a lack of specific receptors in the intestinal $\operatorname{tract}^{(8)}$.

To date, there is a lack of long-term studies conducted with a large number of animals over several generations with the objective of evaluating the effects of GM feeds on livestock species $^{(11)}$. Multigenerational studies evaluating the long-term effects of feeding GM feed have been confined to sheep ${ }^{(12)}$, mice $^{(13)}$ and rats ${ }^{(14,15)}$, and have not been conducted to date in pigs, perhaps the best recognised animal model for human physiology ${ }^{(16)}$. Results from one multigenerational feeding study in which mice were fed 33\% NK603 × MON810 GM maize compared with non-GM maize concluded that litter size and weight in the third and fourth litters of continuous breeding were decreased in the GM maize-fed group ${ }^{(13)}$. However, concerns were raised by researchers as to the validity of this research due to perceived flaws in the statistical analysis of the data ${ }^{(17)}$. The study was subsequently withdrawn by the Austrian government and the European Food Safety Authority Scientific Panel on Genetically Modified Organisms concluded that 'on the basis of the data presented the Genetically Modified Organisms Panel is of the opinion that no conclusions can be drawn from the report ${ }^{(18)}$.

The primary objective of the present study was to examine the cross-generational effects of feeding Bt MON810 maize on maternal and offspring health in an animal more appropriately used as a model for humans. The present investigation is part of a larger study examining the trans-generational effect of exposure to GM maize on growth and health indicators in pigs (St Buzoianu, Mc Walsh, MC Rea, et al., unpublished result).

\section{Materials and methods}

\section{Animal welfare}

The present animal study complied with the European Union Council Directive 91/630/EEC (outlines minimum standards for the protection of pigs) and 98/58/EC (concerns the protection of animals kept for farming purposes) and was approved by, and a license obtained from, the Irish Department of Health and Children (licence no. B100/4147). Ethical approval was obtained from the Teagasc and Waterford Institute of Technology ethics committees.

\section{Experimental design and diets}

A total of twenty-four cross-bred (Large White $\times$ Landrace) nulliparous sows and their offspring were used in a 20 -week study. At service, sows (approximately $165 \mathrm{~kg}$ ) were blocked by body weight (BW) and service date and randomly assigned to one of two dietary treatments: (1) non-GM isogenic parent line maize (Pioneer PR34N43) and (2) GM maize (Pioneer PR34N44 event MON810). Sows were fed the experimental diets from service throughout gestation and lactation until litters were weaned at approximately $28 \mathrm{~d}$ post-farrowing (Table 1 ).

Seeds derived from GM Bt MON810 and non-GM parent line control maize (PR34N44 and PR34N43, respectively; Pioneer Hi-Bred) were grown simultaneously side by side in

Table 1. Composition of sow gestation and lactation diets (fresh weight basis, \%)

\begin{tabular}{|c|c|c|c|c|}
\hline \multirow[b]{2}{*}{ Ingredients (\%) } & \multicolumn{2}{|c|}{ Gestation } & \multicolumn{2}{|c|}{ Lactation } \\
\hline & Non-GM & GM & Non-GM & GM \\
\hline Maize (non-GM) & 86.55 & - & 74.42 & - \\
\hline Maize (GM MON810) & - & 86.55 & - & 74.42 \\
\hline Soyabean meal (non-GM) & $10 \cdot 33$ & $10 \cdot 33$ & $19 \cdot 30$ & $19 \cdot 30$ \\
\hline Soyabean oil & - & - & 3.02 & 3.02 \\
\hline Lys $\mathrm{HCl}(78.8)$ & $0 \cdot 16$ & 0.16 & 0.25 & 0.25 \\
\hline DL-Met & - & - & $0 \cdot 10$ & $0 \cdot 10$ \\
\hline L-Thr (98) & - & - & 0.06 & 0.06 \\
\hline Vitamin and mineral premix ${ }^{\star}$ & $0 \cdot 10$ & $0 \cdot 10$ & $0 \cdot 10$ & $0 \cdot 10$ \\
\hline Salt feed grade & 0.40 & 0.40 & 0.40 & 0.40 \\
\hline Dicalcium phosphate & 1.36 & 1.36 & 1.29 & 1.29 \\
\hline Limestone flour & $1 \cdot 10$ & $1 \cdot 10$ & 1.06 & 1.06 \\
\hline \multicolumn{5}{|c|}{ Analysed chemical composition (\%) } \\
\hline DM & 88.40 & 87.80 & $89 \cdot 50$ & $88 \cdot 60$ \\
\hline Crude protein & 11.80 & 11.00 & $15 \cdot 60$ & $15 \cdot 00$ \\
\hline Fat & 3.00 & $3 \cdot 20$ & $5 \cdot 90$ & $6 \cdot 00$ \\
\hline Crude fibre & $1 \cdot 70$ & 1.60 & 1.60 & 1.90 \\
\hline Ash & $4 \cdot 10$ & $4 \cdot 30$ & 4.60 & $4 \cdot 30$ \\
\hline Lys & 0.64 & 0.68 & 1.01 & 0.96 \\
\hline Ca† & $7 \cdot 60$ & $7 \cdot 60$ & $7 \cdot 50$ & $7 \cdot 50$ \\
\hline $\mathrm{P} \dagger$ & $6 \cdot 10$ & $6 \cdot 10$ & $6 \cdot 20$ & $6 \cdot 20$ \\
\hline Digestible energy $(\mathrm{MJ} / \mathrm{kg})^{\dagger}$ & 13.80 & 13.80 & 14.50 & 14.50 \\
\hline
\end{tabular}

* Premix provided per kg of complete diet: Cu, $15 \mathrm{mg}$; Fe, $70 \mathrm{mg}$; Mn, $62 \mathrm{mg}$; Zn, $80 \mathrm{mg}$; I, 0.6 mg; Se, $0.2 \mathrm{mg}$; retinyl acetate, $3.44 \mathrm{mg}$; cholecalciferol, $25 \mu \mathrm{g}$; DL- $\alpha$-tocopheryl acetate, $100 \mathrm{mg}$ vitamin $\mathrm{K}, 2 \mathrm{mg}$; vitamin $\mathrm{B}_{12}$, $15 \mu \mathrm{g}$; riboflavin, $5 \mathrm{mg}$; nicotinic acid, $12 \mathrm{mg}$; pantothenic acid, $10 \mathrm{mg}$; choline chloride, $500 \mathrm{mg}$; biotin, $200 \mu \mathrm{g}$; folic acid, $5 \mathrm{mg}$ vitamin $\mathrm{B}_{1}, 2 \mathrm{mg}$; vitamin $\mathrm{B}_{6}, 3 \mathrm{mg}$

†Calculated values. 
2007 in Valtierra, Navarra, Spain by independent tillage farmers. GM and non-GM control maize were purchased by the authors from the tillage farmers for use in the present animal study. Samples from GM and non-GM maize were tested for chemical, amino acid and carbohydrate composition as well as for the presence of the $c r y 1 A b$ gene, pesticide contaminants and mycotoxins, as previously described by Walsh et $a l .{ }^{(19)}$.

All diets were manufactured and analysed for chemical composition and amino acid concentration as previously described by Walsh et al. ${ }^{(19)}$. Sampling of the diets was conducted in accordance with international guidelines ${ }^{(20)}$. All diets were formulated to meet or exceed the National Research Council requirements ${ }^{(21)}$ for pigs at the relevant stage of the production cycle. From selection at $100 \mathrm{~kg}$ until service, gilts were fed a non-GM gilt developer diet (13.67 MJ digestable energy/kg, $6.0 \mathrm{~g}$ lysine $/ \mathrm{kg}$ ). Sows were fed either non-GM or GM maize-based gestation diets from service until farrowing (approximately 115d). Following farrowing, sows were fed either non-GM or GM maize-based lactation diets until litters were weaned (approximately $28 \mathrm{~d}$ of age). Creep feed was not offered to suckling piglets.

\section{Housing and management}

Gilts were purchased from Hermitage AI as weanling pigs (approximately 28d old) and raised to approximately $165 \mathrm{~kg}$ in the Moorepark pig unit. During this time, gilts received diets that were free of GM ingredients. At approximately $100 \mathrm{~kg}$, gilts were selected for service based on weight and desirable conformation traits (leg conformation and nipple number and position) and housed in gilt accommodation until 1 week before service. Gilts were restrictively fed during this time, receiving $2.5 \mathrm{~kg}$ of gilt developer diet per $\mathrm{d}$. Synchronisation of sow oestrus was achieved by administering $20 \mathrm{mg}$ of altrenogest (Regumate; Intervet/Schering-Plough Animal Health) per gilt in feed for $18 \mathrm{~d}$. Following administration of altrenogest, the gilts were moved to the service area where they remained until service. A sexually mature boar was housed in the room to stimulate the gilts to come into oestrus. At $9 \mathrm{~d}$ before predicted oestrus, the gilts were flush fed the gilt developer diet $(4 \mathrm{~kg} / \mathrm{d})$. Gilts were inseminated with pooled semen from five Hylean MaxGro ${ }^{\mathrm{TM}}$ boars (Hermitage AI) as soon as oestrus was detected and again $24 \mathrm{~h}$ later. After service, gilts were transferred to dry sow accommodation and were penned individually in basket stalls $(2.4 \mathrm{~m} \times 0.6 \mathrm{~m}$; O'Donovan Engineering) until day 110 of gestation. Environmental temperature was maintained between 20 and $22^{\circ} \mathrm{C}$ and gilts had ad libitum access to water through a single nipple drinker per pen (Arato).

Verification of pregnancy was carried out $28 \mathrm{~d}$ after service using an ultrasound scanner (Oviscan 4 BCF Technology Limited). Gilts found not to be pregnant at the ultrasound scan or at any other time point (exhibiting heat or following abortion) were removed from the study. On days 74 and 99 of gestation, gilts were routinely vaccinated against Escherichia coli (Porcoli Diluvac Forte; Intervet/Schering-Plough Animal Health). Deworming of gilts was performed on day 110 of gestation by administering Zerofen $4 \%$ powder (Chanelle Animal Health Limited) in feed $(0.125 \mathrm{~g} / \mathrm{kg} \mathrm{BW})$.

From day 110 of gestation until weaning, gilts were accommodated in three farrowing rooms with ten pens per room. National Pig Development company-type farrowing crates (O'Donovan Engineering) were used. Environmental temperature was maintained at $20^{\circ} \mathrm{C}$ except around farrowing when the temperature was increased to $24^{\circ} \mathrm{C}$ for $48 \mathrm{~h}$. The dietary treatments were equally represented in each room to avoid additional variation due to environment. Gilts were fed $2 \mathrm{~kg} / \mathrm{d}$ immediately post-farrowing and feed allowance was incrementally increased by $500 \mathrm{~g} / \mathrm{d}$ until day 7 post-farrowing when sows were feeding ad libitum. Gilts had access to feed from an ad libitum feeder (Daltec A/S) and unlimited access to water through a single nipple waterer (Arato), and supplemental water was provided by lever valve where necessary. Care was taken to minimise feed wastage and any soiled or stale feed was removed and accounted for. On day 114 of gestation, gilts were treated with $2 \mathrm{ml}$ of Enzaprost $(5 \mathrm{mg} / \mathrm{ml}$; CEVA Animal Health Limited) to induce farrowing $24-36 \mathrm{~h}$ later.

\section{Body weight and back-fat depth}

Back-fat depth and BW of sows were recorded at service, on days 56 and 110 of gestation and at weaning. Back-fat depth was recorded at the $\mathrm{P} 2$ position $(65 \mathrm{~mm}$ down from the midline, at the level of the head of the last rib), using a Renco Lean Meater (Renco Corporation).

\section{Variables measured at farrowing}

Individual BW of piglets in all litters was recorded at birth and weaning, and average daily gain was calculated during the suckling period. At farrowing, the fourth piglet born alive from each litter (twelve per treatment) was killed by captive bolt stunning followed by exsanguination. Blood samples were taken for haematology and biochemical analysis as outlined below. Heart, kidneys, spleen and liver were removed, trimmed of any superficial fat or blood, blotted dry and weighed.

\section{Blood sampling and analysis}

Blood samples were collected from the external jugular vein of sows (twelve per treatment) before service, on days 28 and 110 of gestation and on day 28 of lactation for serum biochemical analysis and haematology. Blood samples for serum biochemistry analysis were collected in evacuated collection tubes containing a silica clotting activator (BD Vacutainer Systems) and allowed to clot at room temperature for $2-3 \mathrm{~h}$ before centrifugation $(1300 \mathrm{~g}$ for $10 \mathrm{~min}$ ). Serum was collected and stored at $-20^{\circ} \mathrm{C}$ for subsequent biochemical analysis. Serum samples were analysed for aspartate aminotransferase (AST), alanine aminotransferase (ALT), $\gamma$-glutamyltransferase (GGT), alkaline phosphatase (ALP), creatinine, urea and total protein (TP) as previously described by Buzoianu et ll. $^{(22)}$. 
Whole blood samples were collected in evacuated $\mathrm{K}_{2}$ EDTA blood collection tubes (Vacuette, Greiner Bio One Limited) and stored at room temperature before haematological analysis which was performed within $6 \mathrm{~h}$ of collection. Whole blood samples were analysed using a Beckman Coulter Ac T Diff haematology analyser (Beckman Coulter Limited). The following parameters were determined: number of erythrocytes, Hb concentration, haematocrit (Hct), mean corpuscular volume, mean corpuscular $\mathrm{Hb}$, mean corpuscular $\mathrm{Hb}$ concentration (MCHC), red cell distribution width, number of platelets and mean platelet volume. Samples were analysed according to the manufacturer's instructions and general haematology recommendations ${ }^{(23)}$.

\section{Statistical analysis}

Sow and offspring growth performance data were analysed as a complete randomised block design using the general linear model procedure of SAS ${ }^{(24)}$ (SAS Institute Inc.) with pig used as the experimental unit. Treatment effect was tested against residual error terms with initial BW and service date as blocking factors. Sow BW, body composition and offspring growth performance, blood biochemistry, and haematology were analysed as a one-factor ANOVA using the general linear model procedure of SAS. Organ weights were also analysed as a one-factor ANOVA using the general linear model procedure of SAS with birth weight as a covariate in the model. Sow serum biochemistry data and haematology were analysed as a repeated measure using the MIXED procedure of SAS with sampling day as the repeated variable. Simple main effects were obtained using the 'slice' option in SAS. Mean separation was performed using the Tukey-Kramer adjustment for multiple comparisons and values recorded before service were used as a covariate in the model. Fixed effects included treatment and sampling day, while block effects were included as a random effect in the model. The number of piglets born alive per litter was used as a covariate in the analysis of erythrocyte count, Hb concentration and Hct. For all tests, the level of significance was $P<0.05$ and tendencies were reported for $0 \cdot 05<P<0 \cdot 10$

\section{Results}

\section{Analysis of non-GM and GM diets}

Similar chemical and amino acid compositions were observed between the non-GM and GM diets (Table 1).

\section{Effect of feeding diets containing non-GM or GM maize on body weight, body composition of sows and growth rate of offspring}

Sows fed the GM maize-based diets were heavier on day 56 of gestation compared with sows fed the non-GM maize diets $(P=0.05$; Table 2 ). On day 110 of gestation, there was no difference in BW between the treatments. There was no difference in back-fat depth between the treatments at any time during the study. The average daily gain of piglets or the variation in average daily gain within litter during the suckling period was not affected by feeding GM maize to sows. Piglets from GM maize-fed sows tended to be lighter at weaning than piglets from non-GM maize-fed sows $(P=0 \cdot 08)$. Litter weaning weight or the within-litter variation in piglet weaning weight was not affected by feeding GM maize to sows. There was no difference in pre-weaning mortality levels per litter between the treatments.

Table 2. Effect of feeding Bt (MON810) maize to sows during gestation and lactation on sow body weight and backfat depth and offspring pre-weaning growth performance

(Mean values with their standard errors, $n$ 12)

\begin{tabular}{|c|c|c|c|c|}
\hline Treatment & $\begin{array}{c}\text { Non-GM maize } \\
\text { Mean }\end{array}$ & $\begin{array}{l}\text { GM maize } \\
\text { Mean }\end{array}$ & SE & $P$ \\
\hline \multicolumn{5}{|l|}{ Sow performance } \\
\hline Body weight at service $(\mathrm{kg})$ & $164 \cdot 3$ & $165 \cdot 2$ & 0.40 & NS \\
\hline Body weight at day 56 of gestation $(\mathrm{kg})$ & 193.8 & $197 \cdot 8$ & 1.20 & * \\
\hline Body weight at day 110 of gestation $(\mathrm{kg})$ & $222 \cdot 2$ & $227 \cdot 1$ & $2 \cdot 38$ & NS \\
\hline Back-fat depth at service $(\mathrm{mm})$ & 18.5 & $17 \cdot 4$ & $0 \cdot 84$ & NS \\
\hline Back-fat depth at day 56 of gestation $(\mathrm{mm})$ & 18.9 & $18 \cdot 7$ & 0.80 & NS \\
\hline Back-fat depth at day 110 of gestation $(\mathrm{mm})$ & $18 \cdot 7$ & $18 \cdot 9$ & 0.56 & NS \\
\hline \multicolumn{5}{|l|}{ Piglet growth performance during lactation } \\
\hline Mean birth weight $(\mathrm{kg}) \ddagger$ & 1.45 & 1.33 & & \\
\hline$A D G(g / d)$ & 229.7 & $206 \cdot 4$ & $10 \cdot 12$ & NS \\
\hline Variation in ADG (\%) & 17.5 & $17 \cdot 7$ & $2 \cdot 15$ & NS \\
\hline Number of piglets weaned/sow & $10 \cdot 6$ & 11.9 & 0.76 & NS \\
\hline Mean weaning weight $(\mathrm{kg})$ & 7.65 & 6.90 & 0.286 & $t$ \\
\hline Litter weaning weight $(\mathrm{kg})$ & $79 \cdot 8$ & $81 \cdot 2$ & 6.49 & NS \\
\hline Variation in weaning weight (\%) & 17.5 & $15 \cdot \overline{6}$ & 1.75 & NS \\
\hline Pre-weaning mortality (number of pigs/litter) & 1.05 & 1.42 & 0.248 & NS \\
\hline
\end{tabular}

ADG, average daily gain.

${ }^{*}$ Mean values were significantly different between the two treatments $(P<0.05)$.

$\dagger$ Mean values tended to be different between the two treatments $(P<0.10)$.

$\ddagger$ No statistical analysis was conducted on piglet birth weight due to inadequate replication to detect statistical differences. 
Effect of feeding the non-GM and GM maize diets to sows during gestation and lactation on serum biochemistry

There tended to be a treatment $\times$ time interaction $(P=0.08)$ for TP in serum (Table 3 ). On day 28 of lactation, the TP concentration in the serum of GM maize-fed sows tended to be lower than in sows fed the non-GM maize diets $(P=0 \cdot 10)$. On day 110 of gestation, sows fed GM maize tended to have lower serum urea compared with non-GM maize-fed sows $(P=0 \cdot 09)$, and serum urea was found to increase during gestation and lactation $(P<0 \cdot 001)$. There tended to be a treatment $\times$ time interaction $(P=0.09)$ for serum creatinine. Serum creatinine was higher in GM maize-fed sows on day 28 of lactation compared with non-GM maize-fed sows $(P<0.05)$. Serum creatinine increased during gestation but had decreased again by day 28 of lactation $(P<0 \cdot 001)$. There was no effect of treatment on ALT or ALP; however, both parameters decreased over time $(P<0 \cdot 001)$. On day 28 of lactation, GGT concentration tended to be greater in the serum of GM maize-fed sows compared with non-GM maize-fed sows $(P=0.07)$. The concentration of GGT in serum decreased during gestation but serum concentrations were higher on day 28 of lactation than on day 28 of gestation $(P<0 \cdot 001)$. There was no effect of treatment on serum AST during the study; however, the concentration of AST decreased during gestation and increased again during lactation $(P<0 \cdot 01)$.

\section{Effect of feeding the non-GM and GM maize diets to sows during gestation and lactation on sow haematology}

Throughout the study, there was no difference in erythrocyte count between sows fed GM or non-GM maize during gestation and lactation (Table 4). Erythrocyte count decreased for all sows during gestation and lactation $(P<0 \cdot 001)$. Likewise, both $\mathrm{Hb}$ concentration and Hct were not different between the treatments throughout the study. Both $\mathrm{Hb}$ concentration and Hct also decreased over time for both treatments $(P<0.001)$. There was no effect of treatment on mean corpuscular volume. An increase over time was found for mean corpuscular $\mathrm{Hb}$ and mean corpuscular volume $(P<0 \cdot 001)$. On day 110 of gestation, feeding GM maize

Table 3. Effect of feeding Bt (MON810) maize to sows during gestation and lactation on serum biochemistry

(Mean values with their standard errors, $n$ 12)

\begin{tabular}{|c|c|c|c|c|c|c|c|}
\hline \multirow[b]{2}{*}{ Days } & \multicolumn{2}{|c|}{ Treatment } & \multirow[b]{2}{*}{ Mean } & \multirow[b]{2}{*}{$\mathrm{SE}$} & \multicolumn{3}{|c|}{$P$} \\
\hline & Non-GM maize & GM maize & & & Treatment & Time & Treatment $\times$ time \\
\hline \multicolumn{8}{|l|}{ Serum total protein $(\mathrm{g} / \mathrm{l})$} \\
\hline Day 28 of gestation & $75 \cdot 0$ & 74.0 & 74.5 & 1.65 & NS & & \\
\hline Day 110 of gestation & 73.5 & 74.8 & 74.2 & 1.62 & NS & & \\
\hline Day 28 of lactation & $75 \cdot 2$ & 71.9 & 73.5 & 1.62 & $t$ & & \\
\hline Mean & 74.6 & $73 \cdot 6$ & & 1.41 & NS & NS & $\dagger$ \\
\hline \multicolumn{8}{|l|}{ Serum urea $(\mathrm{mmol} / \mathrm{l})$} \\
\hline Day 28 of gestation & $2 \cdot 20$ & $2 \cdot 10$ & $2 \cdot 11$ & 0.207 & NS & & \\
\hline Day 110 of gestation & 2.54 & 2.04 & $2 \cdot 29$ & 0.207 & $t$ & & \\
\hline Day 28 of lactation & 4.23 & $4 \cdot 26$ & 4.29 & 0.216 & NS & & \\
\hline Mean & 3.02 & 2.77 & & 0.142 & NS & $\star \star \star *$ & NS \\
\hline \multicolumn{8}{|l|}{ Serum creatinine $(\mu \mathrm{mol} / \mathrm{l})$} \\
\hline Day 28 of gestation & $142 \cdot 6$ & 141.6 & $142 \cdot 1$ & $4 \cdot 13$ & NS & & \\
\hline Day 110 of gestation & 195.6 & $205 \cdot 2$ & $200 \cdot 4$ & 4.13 & NS & & \\
\hline Day 28 of lactation & $156 \cdot 1$ & $169 \cdot 3$ & $162 \cdot 7$ & 4.28 & * & & \\
\hline Mean & $164 \cdot 8$ & $172 \cdot 0$ & & 3.15 & NS & $\star \star \star \star ~$ & $\dagger$ \\
\hline \multicolumn{8}{|c|}{ Alanine aminotransferase (units/l) } \\
\hline Day 28 of gestation & 33.6 & $36 \cdot 8$ & $35 \cdot 2$ & 1.54 & NS & & \\
\hline Day 110 of gestation & $29 \cdot 3$ & $30 \cdot 6$ & 29.9 & 1.54 & NS & & \\
\hline Day 28 of lactation & $27 \cdot 8$ & $27 \cdot 2$ & $27 \cdot 0$ & 1.61 & NS & & \\
\hline Mean & 29.9 & 31.5 & & 1.04 & NS & 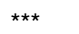 & NS \\
\hline \multicolumn{8}{|c|}{ Alkaline phosphatase (units/l) } \\
\hline Day 28 of gestation & $73 \cdot 7$ & 73.4 & 73.6 & 3.55 & NS & & \\
\hline Day 110 of gestation & $57 \cdot 8$ & $57 \cdot 7$ & $57 \cdot 8$ & 3.55 & NS & & \\
\hline Day 28 of lactation & 47.5 & $45 \cdot 8$ & $46 \cdot 7$ & $3 \cdot 70$ & NS & & \\
\hline Mean & $59 \cdot 7$ & $59 \cdot 0$ & & 2.38 & NS & *** & NS \\
\hline \multicolumn{8}{|c|}{$\gamma$-Glutamyltransferase (units/l) } \\
\hline Day 28 of gestation & $51 \cdot 1$ & 55.4 & $53 \cdot 1$ & 3.39 & NS & & \\
\hline Day 110 of gestation & 47.5 & $47 \cdot 8$ & $47 \cdot 7$ & $3 \cdot 39$ & NS & & \\
\hline Day 28 of lactation & $61 \cdot 1$ & $70 \cdot 6$ & $65 \cdot 8$ & 3.50 & $\dagger$ & & \\
\hline Mean & $53 \cdot 3$ & 57.9 & & $2 \cdot 69$ & NS & *** & NS \\
\hline \multicolumn{8}{|c|}{ Aspartate aminotransferase (units/l) } \\
\hline Day 28 of gestation & $22 \cdot 1$ & $21 \cdot 3$ & $21 \cdot 7$ & 1.99 & NS & & \\
\hline Day 110 of gestation & $20 \cdot 7$ & $18 \cdot 3$ & 19.5 & 1.99 & NS & & \\
\hline Day 28 of lactation & $24 \cdot 2$ & $27 \cdot 6$ & $25 \cdot 9$ & 2.08 & NS & & \\
\hline Mean & $22 \cdot 3$ & 22.4 & & 1.47 & NS & ** & NS \\
\hline
\end{tabular}

Mean values were significantly different between the two treatments: ${ }^{\star} P<0.05,{ }^{\star \star} P<0.01,{ }^{\star \star \star} P<0.001$.

$\dagger$ Mean values tended to be different between the two treatments $(P<0 \cdot 10)$. 
Table 4. Effect of feeding Bt (MON810) maize to sows during gestation and lactation on haematology

(Mean values with their standard errors, $n 12$ )

\begin{tabular}{|c|c|c|c|c|c|c|c|}
\hline \multirow[b]{2}{*}{ Days } & \multicolumn{2}{|c|}{ Treatment } & \multirow[b]{2}{*}{ Mean } & \multirow[b]{2}{*}{ SE } & \multicolumn{3}{|c|}{$P$} \\
\hline & Non-GM maize & GM maize & & & Treatment & Time & Treatment $\times$ time \\
\hline \multicolumn{8}{|c|}{ Erythrocytes $(1000000 / \mu l)$} \\
\hline Day 28 of gestation & 7.79 & 7.68 & 7.73 & 0.128 & NS & & \\
\hline Day 110 of gestation & $6 \cdot 60$ & 6.64 & $6 \cdot 62$ & 0.111 & NS & & \\
\hline Day 28 of lactation & 5.85 & $5 \cdot 67$ & 5.76 & 0.114 & NS & & \\
\hline Mean & $6 \cdot 74$ & $6 \cdot 67$ & & 0.096 & NS & $* * *$ & NS \\
\hline \multicolumn{8}{|l|}{$\mathrm{Hb}(\mathrm{g} / \mathrm{l})$} \\
\hline Day 28 of gestation & 156 & 151 & 153 & $2 \cdot 1$ & NS & & \\
\hline Day 110 of gestation & 132 & 131 & 132 & $2 \cdot 1$ & NS & & \\
\hline Day 28 of lactation & 118 & 112 & 115 & $2 \cdot 2$ & NS & & \\
\hline Mean & 135 & 131 & & 1.4 & NS & *** & NS \\
\hline \multicolumn{8}{|l|}{ Haematocrit (litres/l) } \\
\hline Day 28 of gestation & 0.443 & 0.442 & 0.443 & 0.0080 & NS & & \\
\hline Day 110 of gestation & 0.384 & 0.386 & 0.385 & 0.0065 & NS & & \\
\hline Day 28 of lactation & 0.348 & 0.334 & 0.341 & 0.0068 & NS & & \\
\hline Mean & 0.391 & 0.387 & & 0.0049 & NS & *** & NS \\
\hline \multicolumn{8}{|l|}{ MCV (fl) } \\
\hline Day 28 of gestation & $56 \cdot 5$ & $57 \cdot 2$ & $56 \cdot 8$ & 0.45 & NS & & \\
\hline Day 110 of gestation & 57.8 & $58 \cdot 1$ & 57.9 & 0.45 & NS & & \\
\hline Day 28 of lactation & 59.0 & $59 \cdot 0$ & 59.0 & 0.47 & NS & & \\
\hline Mean & $57 \cdot 7$ & $58 \cdot 1$ & & 0.34 & NS & $* \star *$ & NS \\
\hline \multicolumn{8}{|l|}{$\mathrm{MCH}(\mathrm{g} / \mathrm{l})$} \\
\hline Day 28 of gestation & 196 & 199 & 198 & $3 \cdot 1$ & NS & & \\
\hline Day 110 of gestation & 202 & 200 & 201 & 2.8 & NS & & \\
\hline Day 28 of lactation & 203 & 200 & 201 & $2 \cdot 8$ & NS & & \\
\hline Mean & 201 & 200 & & 2.5 & NS & NS & NS \\
\hline \multicolumn{8}{|l|}{$\mathrm{MCHC}(\%)$} \\
\hline Day 28 of gestation & 34.4 & 34.3 & 34.4 & 0.16 & NS & & \\
\hline Day 110 of gestation & 34.6 & 34.1 & $34 \cdot 3$ & 0.13 & * & & \\
\hline Day 28 of lactation & 33.8 & 33.8 & 33.8 & 0.13 & NS & & \\
\hline Mean & 34.3 & 34.1 & & 0.09 & NS & *** & NS \\
\hline \multicolumn{8}{|l|}{ RDW (\%) } \\
\hline Day 28 of gestation & $18 \cdot 0$ & $17 \cdot 7$ & $17 \cdot 8$ & 0.25 & NS & & \\
\hline Day 110 of gestation & $17 \cdot 6$ & $17 \cdot 8$ & $17 \cdot 7$ & 0.25 & NS & & \\
\hline Day 28 of lactation & $18 \cdot 2$ & $18 \cdot 3$ & $18 \cdot 3$ & 0.26 & NS & & \\
\hline Mean & 17.9 & 17.9 & & 0.20 & NS & ** & NS \\
\hline \multicolumn{8}{|l|}{ Platelets $(1000 / \mu \mathrm{l})$} \\
\hline Day 28 of gestation & 252.6 & 269.6 & $261 \cdot 1$ & $24 \cdot 0$ & NS & & \\
\hline Day 110 of gestation & $264 \cdot 1$ & $215 \cdot 8$ & 239.9 & 23.1 & $t$ & & \\
\hline Day 28 of lactation & $348 \cdot 3$ & 383.0 & $365 \cdot 7$ & $24 \cdot 0$ & NS & & \\
\hline Mean & 288.3 & 289.5 & & 17.9 & NS & NS & $t$ \\
\hline \multicolumn{8}{|l|}{ MPV (fl) } \\
\hline Day 28 of gestation & 7.99 & 8.17 & 8.08 & 0.15 & NS & & \\
\hline Day 110 of gestation & $9 \cdot 12$ & 8.93 & 9.02 & 0.15 & NS & & \\
\hline Day 28 of lactation & 8.47 & 8.66 & 8.56 & $0 \cdot 16$ & NS & & \\
\hline Mean & 8.52 & 8.59 & & $0 \cdot 10$ & NS & *** & NS \\
\hline
\end{tabular}

MCV, mean corpuscular volume; $\mathrm{MCH}$, mean corpuscular $\mathrm{Hb}$; MCHC, mean corpuscular $\mathrm{Hb}$ concentration; RDW, red cell distribution width; MPV, mean platelet volume. Mean values were significantly different between the two treatments: ${ }^{\star} P<0.05,{ }^{\star \star} P<0.01,{ }^{\star \star \star} P<0.001$.

$\dagger$ Mean values tended to be different between the two treatments $(P<0 \cdot 10)$.

resulted in lower MCHC in blood $(P=0.05)$ compared with non-GM maize. MCHC in blood decreased during gestation and lactation $(P<0 \cdot 001)$. There was no effect of feeding GM maize on red cell distribution width in blood and red cell distribution width was found to increase over time $(P<0 \cdot 01)$. There tended to be a treatment $\times$ time interaction $(P=0.07)$ for blood platelet count. On day 110 of gestation, there tended $(P=0 \cdot 10)$ to be fewer platelets in the blood of GM maize-fed sows than in non-GM maize-fed sows. There was no effect of treatment on mean platelet volume in blood and mean platelet volume was found to increase during gestation but decrease during lactation $(P<0 \cdot 001)$.
Effect of feeding the non-GM and GM maize diets to sows during gestation on serum biochemistry, haematology and organ weight of offspring at birth

There was no effect of feeding GM maize to sows during gestation on the heart, liver, kidneys and spleen weight of offspring at birth (Table 5). TP and creatinine in the serum of offspring at birth were unaffected by the treatment; however, the offspring of sows fed GM maize tended to have lower serum urea than the offspring from sows fed non-GM maize $(P=0.08)$. The concentration of the liver enzymes ALT, AST, GGT and ALP in the serum of offspring at birth was not 
Table 5. Effect of feeding Bt (MON810) maize to sows during gestation on offspring organ weight, blood biochemistry and haematology at birth

(Mean values with their standard errors, $n$ 12)

\begin{tabular}{|c|c|c|c|c|}
\hline Treatment & $\begin{array}{c}\text { Non-GM maize } \\
\text { Mean }\end{array}$ & $\begin{array}{c}\text { GM maize } \\
\text { Mean }\end{array}$ & SE & $P$ \\
\hline \multicolumn{5}{|l|}{ Organ weight (g)† } \\
\hline Heart & 9.85 & $9 \cdot 84$ & 0.340 & NS \\
\hline Kidneys & $9 \cdot 88$ & $9 \cdot 77$ & 0.539 & NS \\
\hline Spleen & 1.28 & $1 \cdot 16$ & 0.069 & NS \\
\hline Liver & $39 \cdot 7$ & 36.9 & 1.93 & NS \\
\hline \multicolumn{5}{|l|}{ Serum biochemistry } \\
\hline Serum total protein $(\mathrm{g} / \mathrm{l})$ & $22 \cdot 2$ & $22 \cdot 8$ & 0.79 & NS \\
\hline Serum urea $(\mathrm{mmol} / \mathrm{l})$ & 3.08 & 2.41 & 0.249 & * \\
\hline Serum creatinine $(\mu \mathrm{mol} / \mathrm{l})$ & $161 \cdot 3$ & $156 \cdot 3$ & $12 \cdot 52$ & NS \\
\hline Alanine aminotransferase (units/l) & $11 \cdot 1$ & $13 \cdot 0$ & 1.04 & NS \\
\hline Aspartate aminotransferase (units/l) & $60 \cdot 9$ & $70 \cdot 8$ & $18 \cdot 28$ & NS \\
\hline$\gamma$-Glutamyltransferase (units/l) & $55 \cdot 2$ & $64 \cdot 3$ & 4.77 & NS \\
\hline Alkaline phosphatase (units/l) & $1968 \cdot 6$ & $2087 \cdot 7$ & 306.59 & NS \\
\hline \multicolumn{5}{|l|}{ Haematology } \\
\hline Erythrocytes $(1000000 / \mu \mathrm{l})$ & 5.79 & 4.50 & 0.707 & NS \\
\hline $\mathrm{Hb}(\mathrm{g} / \mathrm{l})$ & $109 \cdot 2$ & 80.5 & 19.04 & NS \\
\hline Haematocrit (litres/l) & 1.73 & $5 \cdot 33$ & 2.56 & NS \\
\hline $\mathrm{MCV}(\mathrm{fl})$ & 81.5 & 62.5 & 14.49 & NS \\
\hline $\mathrm{MCH}(\mathrm{g} / \mathrm{l})$ & $191 \cdot 3$ & $220 \cdot 4$ & 13.46 & NS \\
\hline $\mathrm{MCHC}(\%)$ & 29.54 & $30 \cdot 50$ & 0.355 & * \\
\hline RDW (\%) & 18.44 & $18 \cdot 31$ & 0.453 & NS \\
\hline Platelets $(1000 / \mu \mathrm{l})$ & $154 \cdot 2$ & $117 \cdot 4$ & 22.45 & NS \\
\hline MPV (fl) & 9.65 & 9.56 & 0.361 & NS \\
\hline
\end{tabular}

$\mathrm{MCV}$, mean corpuscular volume; $\mathrm{MCH}$, mean corpuscular $\mathrm{Hb}$; $\mathrm{MCHC}$, mean corpuscular $\mathrm{Hb}$ concentration; RDW, red cell distribution width; MPV, mean platelet volume.

* Mean values tended to be different between the two treatments $(P<0 \cdot 10)$.

†Organ weight data were analysed using birth weight as a covariate in the model.

different between the treatments. There was no effect of treatment on erythrocyte count, $\mathrm{Hb}$, Hct, mean corpuscular volume, mean corpuscular $\mathrm{Hb}$, red cell distribution width, platelet count and mean platelet volume measured in the blood of offspring at birth. The offspring of sows fed GM maize tended to have a higher MCHC in blood than the offspring from non-GM maize-fed sows $(P=0 \cdot 08)$.

\section{Discussion}

This is the first study in pigs to examine the transgenerational effect of GM maize exposure on the health of both dam and offspring. The results from the present study indicate that feeding GM maize to sows during gestation does not affect body composition as determined by back-fat depth, and differences in BW observed between the treatments at mid-gestation were not present in late gestation. Parallel to the present findings, TrabalzaMarinucci et $a l .{ }^{(12)}$ found that feeding Bt176 maize to sheep over a 3-year period had no effect on BW or the body condition score. A study in which cows were fed Bt MON810 maize over two successive lactations revealed a decrease in body condition score and weight during the second lactation in the GM maizefed group ${ }^{(25)}$. Steinke et al. ${ }^{(25)}$ concluded that the observed differences in body condition score and weight in cows could be attributed to biological variation rather than GM maize exposure as values were still within the normal biological range for these animals.

The present study was not designed to evaluate the effects of GM maize feeding on sow reproductive performance but rather on sow and offspring growth and health. Additional studies with much greater replication are necessary to assess the effects of GM maize on the reproductive performance of sows. However, although not thought to be related to treatment, the present study found that GM maize-fed sows gave birth to numerically more live-born piglets ( 2.5 piglets/litter) than non-GM maize-fed sows. As a consequence of numerically more piglets born to and reared by GM maize-fed sows (1.3 extra piglets weaned/litter), the weaning weight of piglets from GM maize-fed sows was less than that of piglets from non-GM maize-fed sows. As piglets were not offered creep feed during the lactation period, the additional suckling pigs would have placed increased demand on the sows' limited milk supply, thereby reducing growth.

Similar to the present findings, results from a sheep study found that feeding Bt176 maize over a 3-year period had no effect on the mortality or growth rate of lambs to weaning ${ }^{(12)}$. The diet of lambs was supplemented before weaning with a mixture of non-GM cereals and faba beans. Likewise, a study on feeding Bt maize to rats found that birth rate and the survival of offspring were not affected by treatment $^{(15)}$.

We previously reported no effect of short-term exposure of Bt MON810 maize on serum TP, creatinine, urea or the liver enzymes AST, ALT and GGT in weanling pigs ${ }^{(19)}$. The results from the present study found that feeding GM maize to sows during gestation and lactation resulted in increased serum creatinine and GGT concentration and reduced serum $\mathrm{TP}$ at the end of lactation and decreased serum urea at the 
end of gestation. However, the measured values were all within the normal reference range for pigs during these reproductive stages $^{(26)}$, and with the exception of serum creatinine none was significantly different. Likewise, offspring from GM maize-fed sows also had decreased serum urea concentrations at birth compared with offspring from non-GM maize-fed sows; however, liver enzyme activity and liver weight at birth were not different between the treatments. Liver dysfunction is characterised by increased GGT concentration; however, this must also be accompanied by a 10-70-fold increase in AST and a 5-10-fold increase in ALP, neither of which were obseved in sows or offspring in the present study ${ }^{(27,28)}$. Similar to the present findings, at the end of lactation, ewes fed Bt176 maize also experienced an increase in GGT concentration in serum; however, there were no effects on serum creatinine, TP, urea, ALP or $\mathrm{AST}^{(12)}$. In agreement with the present findings, serum TP was found to be lower in rats fed Bt maize during a three-generation study ${ }^{(15)}$. Kilic \& Akay $^{(15)}$ also reported a decrease in plasma creatinine, which was in contrast to the present results. Likewise, Poulsen et $a l .{ }^{(29)}$ observed a lower creatinine concentration together with increased plasma activity of ALT in female rats fed GM rice. The change in sow serum urea documented in the present study was transient and isolated to day 110 of gestation which questions the biological relevance of this change, but this may account for the decrease observed in serum urea in their offspring. Kidney dysfunction is characterised by elevated serum urea and creatinine, low serum $\mathrm{TP}^{(27,30,31)}$ and increased urinary protein:creatinine ratio ${ }^{(30)}$. While urinary protein and creatinine were not measured during the present study, serum TP was reduced and serum creatinine was increased in sows fed GM maize at the end of lactation in the present study. Nonetheless, there was no change in serum urea and the observed changes in creatinine and TP at day 28 of lactation were small and remained within the normal reference range for these parameters in sows during gestation and lactation. Offspring serum TP, creatinine and kidney weight were not different regardless of the dietary treatment of their dam. Therefore, there is a lack of evidence that changes in blood biochemistry observed in sows during the present study conform to a pattern indicative of either liver or kidney dysfunction or that these changes have any major effect on the organ function of their offspring at birth.

In the present study, feeding GM maize to sows had no effect on erythrocyte count, $\mathrm{Hb}$ concentration and Hct during gestation and lactation. Likewise, feeding GM maize to sows had no effect on haematological parameters of their offspring as no treatment differences were detected in erythrocyte count, $\mathrm{Hb}$ concentration and Hct. Similar to the present findings, a rat study in which haematological parameters were measured in response to feeding GM rice expressing Cry1Ab found no effect of treatment ${ }^{(32)}$. In contrast, however, Trabalza-Marinucci et $a l^{(12)}$ reported an increase in $\mathrm{Hb}$ in sheep fed Bt176 maize. The trend for a decrease in platelet count and a decrease in MCHC observed at the end of gestation in GM maize-fed sows in the present study was transient and minimal, and is unlikely to be of biological significance. Offspring from sows fed GM maize were found to have a tendency for an increase in MCHC at birth; however, this was not accompanied by any other changes in haematology and was contrary to the decrease in MCHC found in their dams. Further research is ongoing by our research group to establish whether changes observed in the offspring of GM maize-fed sows at birth will affect the lifetime performance of these pig. This will help to determine the biological relevance of these changes.

In the present study, the effects of feeding GM maize were evaluated based on comparisons made between GM maize and its isogenic counterpart. Subsequent work conducted by our group using another GM ingredient (MC Walsh, St Buzoianu, D Reiner, et al., unpublished results) included other conventional varieties in safety evaluation. Differences were observed in some of the physiological parameters measured between the two conventional non-GM varieties. These findings highlight the importance of including other conventional varieties when evaluating the effects of a GM ingredient.

In conclusion, feeding Bt MON810 maize to sows during gestation and lactation had no effect on the back-fat depth of sows, and the increase in BW on day 56 of gestation was not observed subsequently. Changes in sow blood biochemistry during the study in response to feeding GM maize did not conform to a pattern indicative of organ dysfunction and were within the normal reference range for sows. No differences in sow haematological parameters were observed between the treatments, with the exception of a tendency for a transient decrease in platelet count and a decrease in MCHC on day 110 of gestation in response to feeding GM maize. There was a minimal effect of feeding GM maize to sows during gestation and lactation on offspring serum biochemistry and haematology at birth and BW at weaning. However, further studies are currently underway to evaluate the lifetime health and growth performance of offspring from $\mathrm{Bt}$ MON810 maize-fed sows.

\section{Acknowledgements}

This study was funded by the European Union's Seventh Framework Programme (FP7/2007-3) under grant agreement no. 211820 and the Teagasc Walsh Fellowship programme and independently of any commercial input, financial or otherwise. None of the authors had a financial or personal conflict of interest with regard to the present study. P. G. L. and R. P. R. secured the funding for the research. P. G. L and G. E. G designed the experiment. M. C. W., S. G. B., P. G. L. and G. E. G. conducted the experiment. M. C. W., S. G. B., G. E. G. and O. O. conducted the laboratory analysis. M. C. W., S. G. B. and P. G. L. wrote the manuscript. All authors read and approved the final manuscript.

\section{References}

1. James C (2011) Global Status of Commericalized Biotech/GM Crops: 2011. ISAAA Brief no. 43. Ithaca, NY: ISAAA. 
2. Bertoni G \& Marsan PA (2005) Safety risks for animals fed genetic modified (GM) plants. Vet Res Commun 29, Suppl. 2, 13-18.

3. Moses V (1999) Biotechnology products and European consumers. Biotechnol Adv 17, 647-678.

4. Malarkey T (2003) Human health concerns with GM crops. Mutat Res 544, 217-221.

5. Paparini A \& Romano-Spica V (2004) Public health issues related with the consumption of food obtained from genetically modified organisms. Biotechnol Annu Rev 10, 85-122.

6. Hug K (2008) Genetically modified organisms: do the benefits outweigh the risks? Medicina (Kaunas) 44, 87-99.

7. EFSA (2011) Panel on Genetically Modified Organisms (GMO); scientific opinion on guidance for risk assessment of food and feed from genetically modified plants. EFSA $J$ 9, 2150.

8. Schnepf E, Crickmore N, Van Rie J, et al. (1998) Bacillus thuringiensis and its pesticidal crystal proteins. Microbiol Mol Biol Rev 62, 775-806.

9. Crickmore N (2005) Using worms to better understand how Bacillus thuringiensis kills insects. Trends Microbiol 13, 347-350.

10. Broderick NA, Robinson CJ, McMahon MD, et al. (2009) Contributions of gut bacteria to Bacillus thuringiensis-induced mortality vary across a range of Lepidoptera. BMC Biol 7, 11 .

11. Zhang W \& Shi F (2011) Do genetically modified crops affect animal reproduction? A review of the ongoing debate. Animal 5, 1048-1059.

12. Trabalza-Marinucci M, Brandi G, Rondini C, et al. (2008) A three-year longitudinal study on the effects of a diet containing genetically modified Bt176 maize on the health status and performance of sheep. Livest Sci 113, 178-190.

13. Velimirov A, Binter C \& Zentek J (2008) Biological effects of transgenic maize NK603 $\times$ MON810 fed in long term reproduction studies in mice. http://biosicherheit.de/pdf/aktuell/ zentek_studie_2008.pdf (accessed 10 August 2011)

14. Rhee GS, Cho DH, Won YH, et al. (2005) Multigeneration reproductive and developmental toxicity study of bar gene inserted into genetically modified potato on rats. $J$ Toxicol Environ Health A 68, 2263-2276.

15. Kilic A \& Akay MT (2008) A three generation study with genetically modified Bt corn in rats: biochemical and histopathological investigation. Food Chem Toxicol 46, $1164-1170$.

16. Patterson JK, Lei XG \& Miller DD (2008) The pig as an experimental model for elucidating the mechanisms governing dietary influence on mineral absorption. Exp Biol Med 233 , 651-664.

17. Monsanto Company (2008) Monsanto company response to Austrian report on mouse chronic and reproduction studies with NK603 × MON810 maize. http://www.monsanto.com. ar/nuestros_productos/informacion_tecnica_seguridad/ documentos/response_to_austrian_gm_study_20nov08.pdf (accessed 10 August 2011).

18. Panel EFSA-GMOEG. (2008) Minutes of the 46th plenary meeting of the panel. http://www.efsa.europa.eu/en/ events/event/gmo081203.htm (accessed 10 August 2011).

19. Walsh MC, Buzoianu SG, Gardiner GE, et al. (2012) Effects of short-term feeding of Bt MON810 maize on growth performance, organ morphology and function in pigs. Br J Nutr $\mathbf{1 0 7}$, 364-371.

20. ILSI (2007) Best Practices for the Conduct of Animal Feed Studies to Evaluate Genetically Modified Crops Washington, DC: ILSI.

21. NRC (1998) Nutrient Requirements of Swine, 10th ed. Washington, DC: National Academy Press.

22. Buzoianu SG, Walsh MC, Rea MC, et al. (2012) Effect of feeding Bt MON810 maize to $\sim 40$-day-old pigs for 110 days on growth and health indicators. Animal (epublication ahead of print 24 February 2012).

23. Feldman BF, Zinkl JG, Jain NC, et al. (2000) Schalm's Veterinary Hematology. Philadelphia, PA: Lippincott Williams \& Wilkins.

24. SAS (2000) SAS User's Guide. Cary, NC: Statistics SAS Institute, Inc.

25. Steinke K, Guertler P, Paul V, et al. (2010) Effects of longterm feeding of genetically modified corn (event MON810) on the performance of lactating dairy cows. J Anim Physiol Anim Nutr 94, e185-e193.

26. Heath MF, Evans RJ \& Gresham AC (1991) Blood biochemical reference ranges for sows under modern management conditions. Br Vet J 147, 331-339.

27. Kaneko JJ (1980) Clinical Biochemistry of Domestic Animalss. 3rd ed. New york: Academic Press.

28. Casteel SW, Turk JR, Cowart RP, et al. (1993) Chronic toxicity of fumonisin in weanling pigs. J Vet Diagn Invest 5, 413-417.

29. Poulsen M, Kroghsbo S, Schrøder M, et al. (2007) A 90-day safety study in Wistar rats fed genetically modified rice expressing snowdrop lectin Galanthus nivalis (GNA). Food Chem Toxicol 45, 350-363.

30. Baum N, Carmelo C \& Carlton CE (1975) Blood urea nitrogen and serum creatinine - physiology and interpretations. Urology 5, 583-588.

31. Stonard MD (1990) Assessment of renal function and damage in animal species. A review of the current approach of the academic, governmental and industrial institutions represented by the Animal Clinical Chemistry Association. J Appl Toxicol 10, 267-274.

32. Schroder M, Poulsen M, Wilcks A, et al. (2007) A 90-day safety study of genetically modified rice expressing Cry1Ab protein (Bacillus thuringiensis toxin) in Wistar rats. Food Chem Toxicol 45, 339-349. 